\title{
PENGARUH PERSEPSI FAKTOR RASIONAL DAN EMOSIONAL TERHADAP KEPUASAN ORANG TUA SISWA DI SEKOLAH DASAR ISLAM TERPADU LENTERA ILMU KOTA TANGERANG
}

\author{
EE JUNAEDI SASTRADIHARJA \\ Institut PTIQ Jakarta \\ edyjs17@yahoo.com \\ WINDY DIAN SARI \\ STAI Fatahillah Serpong \\ windyds09@gmail.com
}

\begin{abstract}
ABSTRAK
Penelitian ini bertujuan untuk mengetahui dan menguji data- data empirik terkait pengaruh persepsi faktor rasional dan emosional terhadap kepuasan orangtua siswa di SDIT Lentera Ilmu. Dalam penelitian ini, penulis menggunakan metode survey dengan pendekatan korelasional dan regresional terhadap data-data kuantitatif yang diperoleh dari objek penelitian yaitu orang tua siswa SDIT Lentera Ilmu. Sampel penelitian ini adalah sebanyak 85 responden. Pengumpulan data dilakukan dengan menggunakan teknik angket/kuesioner, observasi dan dokumentasi. Jenis analisis yang digunakan adalah analisa korelasi dan regresi yang djabarkan secara deskriptif. Hasil dari penelitian ini adalah: Pertama, terdapat pengaruh yang positif dan signifikan persepsi faktor rasional terhadap kepuasan orang tua siswa. Hal ini dapat di lihat dari koefisien korelasi (r) sebesar 0,591 dan koefisien determinasi atau besarnya pengaruh $\left(\mathrm{R}^{2}\right) R$ square sebesar $34,9 \%$. Arah pengaruh ditunjukkan dengan persamaan regresi sederhana $\hat{Y}=25,058+0,795 X_{1}$ yang berarti bahwa setiap peningkatan satu unit skor persepsi faktor rasional $\left(X_{1}\right)$ akan mempengaruhi peningkatan skor kepuasan orang tua siswa (Y) sebesar 0,795. Kedua, terdapat pengaruh yang positif dan signifikan persepsi faktor emosional terhadap kepuasan orang tua siswa dengan koefisien korelasi ( $r$ ) sebesar 0,639 dan koefisien determinasi atau besarnya pengaruh $\left(\mathrm{R}^{2}\right) R$ square sebesar $40,8 \%$. Persamaan regresi $\hat{Y}=50,089+$ $0,653 \mathrm{X}_{2}$, yang berarti bahwa setiap peningkatan satu unit skor persepsi faktor emosional akan mempengaruhi peningkatan skor kepuasan orang tua siswa (Y) sebesar 0,653. Ketiga, terdapat pengaruh yang positif dan signifikan persepsi faktor rasional dan persepsi faktor emosional secara simultan terhadap kepuasan orang tua siswa. Koefisien korelasi (r) sebesar 0,693 sedangkan koefisien determinasi $\left(\mathrm{R}^{2}\right)$ sebesar $48 \%$. Persamaan regresi $\hat{Y}=12,269+0,444 \mathrm{X}_{1}+0,456 \mathrm{X}_{2}$ yang berarti bahwa setiap peningkatan satu unit skor persepsi faktor rasional $\left(X_{1}\right)$ dan persepsi faktor emosional $\left(X_{2}\right)$ secara bersama-sama, akan mempengaruhi peningkatan skor kepuasan orang tua siswa (Y) sebesar 0,900.
\end{abstract}

Kata Kunci: Persepsi Faktor Rasional, Emosional, Kepuasan Orang Tua. 


\begin{abstract}
This study aims to determine and test empirical data related to the influence of perceptions of rational and emotional factors on parents' satisfaction at SDIT Lentera Ilmu. In this study, the authors used a survey method with a correlational and regressional approach to quantitative data obtained from the research object, namely parents of SDIT Lentera Ilmu students. The sample of this study was 85 respondents. Data collection is done by using a questionnaire / questionnaire, observation and documentation. The type of analysis used is correlation analysis and regression which is described descriptively. The results of this study are: First, there is a positive and significant influence on the perception of rational factors on parents' satisfaction. This can be seen from the correlation coefficient (r) of 0.591 and the coefficient of determination or the amount of influence (R2) R square of $34.9 \%$. The direction of influence is shown by a simple regression equation $\hat{Y}=25.058+0.795 X 1$, which means that each increase in one unit of rational factor perception score (X1) will affect an increase in student parent satisfaction score (Y) of 0.795. Secondly, there is a positive and significant influence on the perception of emotional factors on parents' satisfaction with a correlation coefficient $(\mathrm{r})$ of 0.639 and a coefficient of determination or magnitude of influence (R2) R square of 40.8\%. Regression equation $\hat{Y}=50.089+0.653 X 2$, which means that each increase in one unit score of perception of emotional factors will affect an increase in student satisfaction scores (Y) of 0.653. Third, there is a positive and significant influence on the perception of rational factors and the perception of emotional factors simultaneously on the satisfaction of students' parents. The correlation coefficient (r) of 0.693 while the coefficient of determination (R2) of $48 \%$. The regression equation $\hat{Y}=12.269+$ $0.444 \mathrm{X} 1+0.456 \mathrm{X} 2$ which means that each increase in one unit of rational factor perception score $(X 1)$ and emotional factor perception $(X 2)$ together, will affect the increase in student satisfaction scores $(\mathrm{Y})$ by 0.900 .
\end{abstract}

Keywords: Rational Factor Perception, Emotional, Parental Satisfaction. 


\section{A. PENDAHULUAN}

Kepuasan orang tua siswa menjadi bagian penting dalam menjamin keberlangsungan sekolah. Terutama sekolah-sekolah swasta yang sumber pendapatannya lebih dominan berasal dan bersumber dari masyarakat. Oleh karena itu pihak sekolah perlu melakukan upaya optimal agar proses belajar mengajar yang dihasilkan dapat memberikan kepuasan tinggi kepada orang tua. Orang tua sebagai salah satu pelanggan sekolah memberikan dukungan atas keberlangsungan lembaga pendidikan ini. Orang tua yang puas atas layanan pendidikan, biasanya memberikan dukungan positif terhadap sekolah. Sebaliknya, orang tua yang merasakan hal-hal negatif, memberikan respon negatif juga. Kegiatan yang diprogramkan oleh sekolah banyak didukung keberhasilannya oleh orang tua.

Pendidikan merupakan fenomena manusia yang fundamental dan mempunyai sifat konstruktif dalam hidup manusia. ${ }^{1}$ Melalui pendidikan, suatu bangsa akan menjadi maju, yakni berubah dari tingkat yang rendah menuju tingkat atau derajat kehidupan yang lebih baik. ${ }^{2}$ Bangsa yang maju adalah bangsa yang dapat mewujudkan cita-cita pendidikannya menjadi lebih baik, sehingga mewujudkan pribadi yang berkualitas sesuai dengan tujuan pendidikan nasional sesuai dengan pernyataan Pasal 3 Undang-Undang RI Nomor 20 Tahun 2003 tentang Sistem Pendidikan Nasional, yang menyebutkan bahwa pendidikan nasional berfungsi mengembangkan kemampuan dan membentuk watak serta peradaban bangsa yang bermartabat dalam rangka mencerdaskan kehidupan bangsa, bertujuan untuk berkembangnya potensi peserta didik agar menjadi manusia beriman dan bertakwa kepada Tuhan Yang Maha Esa, berakhlak mulia, sehat, berilmu, cakap, kreatif, mandiri, dan menjadi warga Negara yang demokratis serta bertanggung jawab.

Dalam konteks filosofis, pendidikan merupakan sistem dan cara meningkatkan kualitas hidup manusia dalam segala aspek kehidupan manusia. Pendidikan merupakan sarana yang paling efektif dan efisien untuk mentransformasikan ilmu pengetahuan, budaya dan sebagainya dari satu generasi ke generasi berikutnya. Pendidikan itu mewakili sebuah aspirasi dari nilai atau mutu yang telah dicita-citakan. ${ }^{3}$

Secara makro, pendidikan dalam konteks Indonesia tak terkecuali dengan PAI dan pendidikan madrasah, berkaitan erat dengan visi pembangunan nasional. Dengan mempertimbangkan masalah pokok bangsa, tantangan

\footnotetext{
${ }^{1}$ Hasbullah, Dasar-dasar Ilmu Pendidikan, Jakarta: PT. Raja Grafindo Persada, 2005, hal. 7.

2 Eva Maghfiroh, "Supervisi Pendidikan Dalam Kredibilitas Tenaga Pendidikan, " dalam Jurnal Tarbiyatuna, 2014, Vol. 7 no.2.

${ }^{3}$ Zahroh, "Total Quality Management: Capaian kualitas Output Melalui Sistem Kontrol Mutu Sekolah, " dalam Jurnal Cendikia, hal.79.
} 
pembangunan yang dihadapi dan capaian pembangunan selama ini, visi pembangunan nasional untuk tahun 2015-2019 adalah: "Terwujudnya Indonesia yang Berdaulat, Mandiri, dan Berkepribadian Berlandaskan Gotong Royong". ${ }^{4}$

Kebijakan Nasional mengenai agama dan madrasah diarahkan pada peningkatan akses, kualitas dan relevansi pendidikan menuju tercapainya kesejahteraan hidup rakyat, kemandirian dan keluhuran budi pekerti, dan kemandirian bangsa yang kuat. Kebijakan ini dilakukan melalui sembilan fokus prioritas, salah satunya adalah program peningkatan kualitas pendidikan agama dan keagamaan, yang di tempuh melalui peningkatan jumlah dan kapasitas guru, kapasitas penyelenggara pendidikan, pemberian bantuan dan fasilitasi, serta pengembangan kurikulum dan metodologi pembelajaran pendidikan agama dan keagamaan yang efektif sesuai dengan Standar Nasional Pendidikan (SNP). ${ }^{5}$

Seiring dengan kemajuan teknologi dan globalisasi, dunia pendidikan berkembang begitu cepat, dan saat ini sedang di guncang oleh berbagai perubahan sesuai dengan tuntutan dan kebutuhan masyarakat, serta di tantang untuk dapat menjawab berbagai permasalahan lokal dan perubahan global yang terjadi begitu pesat. Era globalisasi yang ditandai dengan persaingan kualitas atau mutu, menuntut semua pihak dalam berbagai bidang dan sektor pembangunan untuk senantiasa meningkatkan kompetensinya. Hal tersebut menunjukkan betapa pentingnya upaya peningkatan kualitas pendidikan baik secara kuantitatif maupun kualitatif yang harus dilakukan terus-menerus. ${ }^{6}$

Pada era globalisasi dan pasar bebas, bangsa Indonesia menghadapi satu era yang kompetitif, ke suasana persaingan yang semakin ketat. Kondisi yang demikian ini dapat diantisipasi dengan kemampuan menyesuaikan diri dengan lingkungan baru yang kompetitif, cara yang paling tepat adalah dengan mempersiapkan sumber daya yang berkualitas untuk menghadapi era globalisasi dan mampu menghadapi tantangan zaman. Gambaran tantangan manusia masa industrialisasi mempunyai ciri-ciri sebagai berikut: 1) kaya informasi (well informed) dan sikap belajar seumur hidup, 2) mampu bernalar secara rasional, 3) memiliki sikap kreatif terhadap tantangan baru, memiliki kemampuan untuk mengantisipasi kemampuan, berinovasi dan bertanggung jawab. ${ }^{7}$

${ }^{4}$ Kementrian Agama, Renstra Kementrian Agama tahun 2015-2019, Jakarta: Setjen Kementerian Agama, 2015, hal.57.

${ }^{5}$ Visi Ditjen Pendidikan Islam yaitu "Terwujudnya Pendidikan Islam yang Unggul, Moderat, dan Menjadi Rujukan Dunia dalam Integrasi Ilmu Agama, Pengetahuan dan Teknologi." Sementara Visi Ditpai adalah "Terwujudnya Lulusan Sekolah Yang Beriman dan Bertaqwa, Taat Beragama, Inlusif, Cerdas, Berpikiran Maju, dan Berakhlak Mulia."

${ }^{6}$ Kementrian Agama, Renstra Kementrian Agama tahun 2015-2019, ... hal. 58.

7 Siti Hasanah, "Aplikasi Total Quality Management (TQM) Dalam Manajemen Pendidikan Islam, “ dalam Jurnal Edukasi, Volume 01, Nomor 02, 2013, hal. 209-224. 
Dalam usaha menyiapkan sumber daya manusia masa depan yang berkualitas pendidikan mengemban amanat yang sangat besar, di mana dunia pendidikan adalah wahana yang lebih besar dalam pembangunan dan pembinaan sumber daya manusia. ${ }^{8}$ Sebagai modal dan pelaku pembangunan dalam negara yang kita cintai ini. Dalam konteks ini, pendidikan semakin dituntut peranannya. Untuk memainkan peranan ini, pendidikan nasional harus di selenggarakan secara adil, relevan, berkualitas, efektif dan efisien.

Pendidikan di Indonesia menghadapi berbagai tantangan, yaitu internal dan eksternal. Tantangan internal pendidikan antara lain terkait dengan kondisi pendidikan dikaitkan dengan tuntutan pendidikan yang mengacu kepada 8 (delapan) Standar Nasional Pendidikan yang meliputi standar isi, standar proses, standar kompetensi lulusan, standar pendidik dan tenaga kependidikan, standar sarana dan prasarana, standar pengelolaan, standar pembiayaan, dan standar penilaian pendidikan. ${ }^{9}$

Tantangan internal lainnya terkait dengan perkembangan penduduk Indonesia dilihat dari pertumbuhan penduduk usia produktif. Saat ini jumlah penduduk Indonesia usia produktif (15-64 tahun) lebih banyak dari usia tidak produktif (anak-anak berusia 0-14 tahun dan orang tua berusia 65 tahun ke atas). Jumlah penduduk usia produktif ini akan mencapai puncaknya pada tahun 2020-2035 pada saat angkanya mencapai 70\%. Oleh sebab itu, tantangan besar yang dihadapi adalah bagaimana mengupayakan agar sumber daya manusia yang memiliki kompetensi dan keterampilan melalui pendidikan agar tidak menjadi beban. ${ }^{10}$

Adapun tantangan eksternal pendidikan di Indonesia antara lain terkait dengan arus globalisasi dan berbagai isu yang terkait dengan masalah lingkungan hidup, kemajuan teknologi dan informasi, kebangkitan industri kreatif dan budaya, dan perkembangan pendidikan di tingkat internasional. Arus globalisasi akan menggeser pola hidup masyarakat dari agraris dan perniagaan tradisional menjadi masyarakat industri dan perdagangan modern.

Pendidikan agama berbeda dengan pendidikan keagamaan. Pendidikan agama lebih menekankan pemberian pengetahuan, pembentukan sikap, kepribadian dan keterampilan peserta didik. Sementara pendidikan keagamaan merupakan pendidikan yang mempersiapkan peserta didik menjadi ahli ilmu agama dan mengamalkan ajaran agamanya. ${ }^{11}$ Urgensi pendidikan agama terhadap pembentukan pribadi perlu diwujudkan. Pribadi-pribadi yang baik akan membentuk masyarakat yang baik. Demikian pula masyarakat yang baik, damai, sejahtera akan membentuk negara yang kuat dan sejahtera. Oleh karena

${ }^{8}$ Soejatmoko, Etika Kebebasan, Jakarta: LP3ES, 1998, hal. 12.

${ }_{9}$ Permendikbud, Standar Isi pada Pendidikan Dasar dan Menengah, 2014, hal. 1.

10 Permendikbud, Standar Isi pada Pendidikan Dasar dan Menengah, ... hal. 3.

${ }^{11}$ Menteri Hukum dan Hak Asasi Manusia RI, Lembaran Negara RI tahun 2007 nomor 124, dalam himpunan peraturan di bidang pendidikan, hal. 199. 
itu, pendidikan agama sebagai salah satu sarana mendidik pribadi di sekolah, perlu diatur pelaksanaannya secara efektif. ${ }^{12}$ Kehadiran sekolah-sekolah asing dan sekolah-sekolah internasional lainnya yang menawarkan programprogram dan fasilitas berstandar internasional telah menarik minat masyarakat untuk menyekolahkan putra-putrinya di sekolah tersebut, dengan harapan dapat menghasilkan lulusan yang berkualitas yang berdaya saing global.

Adanya kompetensi dan persaingan global ini, tentu menuntut adanya profesionalitas baik bagi kepala sekolah maupun guru dalam melaksanakan tugas pokok dan fungsinya masing-masing. Kepala sekolah dituntut mampu melaksanakan tujuh tugas pokok dan fungsinya yakni 1) Kepala sekolah selaku edukator; memiliki tugas pokok untuk melaksanakan kegiatan pembelajaran secara efektif dan efisien, sehingga mampu mewujudkan kualitas pendidikan yang baik. 2) Kepala sekolah selaku manajer, memiliki tugas menyusun perencanaan, mengorganisasikan kegiatan, mengarahkan sumber daya yang ada, mengkooordinasikan, melakukan pengawasan, melakukan evaluasi terhadap kegiatan, menentukan kebijaksanaan, mengadakan rapat, mengambil keputusan, mengatur proses belajar mengajar, mengatur administrasi Ketatausahaan, siswa, ketenangan, sarana dan prasarana, keuangan/RAPBS, mengatur Organisasi Siswa Intra Sekolah (OSIS), dam mengatur hubungan sekolah dengan masyarakat dan instansi terkait. 3) Kepala sekolah sebagai administrator bertugas menyelenggarakan Administrasi; perencanaan, pengorganisasian, pengarahan, pengkoordinasian, pengawasan, kurikulum, kesiswaan, ketatausahaan, ketenagaan, kantor, keuangan, perpustakaan, laboratorium, ruang keterampilan /kesenian, Bimbingan Konseling, UKS, serbaguna, media, gudang. 4) Kepala sekolah selaku supervisor bertugas menyelenggarakan supervisi dan pengawasan pendidikan. 5) Kepala sekolah selaku leader; yaitu mempengaruhi bawahannya agar dapat bekerjasama dalam mencapai tujuan organisasi sekolah. 6) Kepala sekolah sebagai inovator; melakukan pembaharuan di bidang pembelajaran, bimbingan konseling, ekstrakurikuler, penigkatan mutu guru dan staf sekolah lainnya, penggalian sumber daya pendidikan dan pengadaan sarana prasarana pendidikan. 7) Kepala sekolah selaku motivator; memberikan semangat dan dorongan kepada guru dan staf sekolah lainnya agar dapat melakukan pekerjaannya dengan sungguh-sungguh dan penuh keikhlasan.

Guru dituntut untuk mampu berfastabiqulkhaerat atau berlomba dalam kebaikan, yaitu dengan meningkatkan mutu pembelajaran di kelas dan membentuk karakter siswa yang bermoral dan berakhlak mulia. Oleh karena semakin baik kualitas pendidikan dan pembelajaran yang dilakukan guru di kelas, maka semakin banyak pula orang tua yang berminat memasukkan putra-

12 Akhmad Shunhaji, Implementasi Pendidikan Agama di Sekolah Katolik Kota Blitar dan Dampaknya Terhadap Interaksi Sosial, Yogyakarta: Aynat Publishing, 2017, hal. 6. 
putrinya di sekolah tersebut. Sekolah yang memiliki kualitas gedung dan sarana pendidikan yang memadai, didukung oleh guru yang memiliki kompetensi baik dan mampu memberikan pelayanan secara profesional, tentu akan menjadi incaran dan rebutan masyarakat.

Kesadaran masyarakat akan pentingnya menanamkan keimanan kepada seorang anak sejak dini berdampak pada berkembangnya Sekolah Dasar Islam Terpadu (SDIT). SDIT kini semakin bertambah dan cenderung tidak sulit lagi menemukan SDIT di berbagai kota. Perkembangan sekolah Islam menjadi tren yang fenomenal di kawasan Asia Tenggara, khususnya Indonesia. Hal itu ditandai dengan munculnya semangat menolak fenomena sekularisme dalam filosofi pendidikan, yakni sekolah yang mengintegrasikan pendidikan umum dan agama dalam suatu jalinan kurikulum, pembelajaran, dan lingkungan terpadu. Hal tersebut tentunya membuat persaingan antar SDIT semakin kompetitif. Semakin kompetitifnya persaingan tersebut tentunya pula perlu mendapat perhatian ekstra dari pengelola sekolah. Dalam hal ini pemerintah belum memiliki SDIT Negeri untuk itu maka sampai saat ini SDIT dikelola oleh pihak swasta. Banyaknya orang tua yang berminat dengan SDIT menyebabkan terjadi persaingan dalam menyediakan pendidikan sekolah dasar islam yang berkualitas.

Di banyak Negara pendidikan hampir dianggap seperti pasar komoditi. ${ }^{13}$ SDIT bersaing untuk menarik calon orang tua siswa sehingga menimbulkan pengambilan keputusan yang lebih kompleks bagi calon orang tua. Akan tetapi, menyekolahkan anak-anak bagi orang tua adalah hak dan kewajiban. Para orang tua memiliki kewajiban untuk memilihkan sekolah bagi anak-anaknya. Informasi pendidikan pun diberikan orang tua untuk menambah wawasan, pengetahuan, dan mengembangkan potensi dan minat anak. Hal ini sebagaimana yang tercantum dalam Undang-Undang Republik Indonesia Nomor 20 Tahun 2003 Tentang Sistem Pendidikan Nasional pasal 7 yang berbunyi (1) Berhak berperan serta dalam memilih satuan pendidikan dan memperoleh informasi tentang perkembangan pendidikan anaknya. (2) Orang tua dari anak usia belajar, berkewajiban memberikan pendidikan dasar kepada anaknya.

Berdasarkan jenis institusi pendidikan, sekolah negri maupun swasta saat ini terus berkompetisi untuk memberikan yang terbaik untuk pendidikan anak. Semakin bagus predikat sekolah, maka orang tua tidak ragu dengan kualitas pendidikan dari sekolah tersebut. Ketika persaingan SDIT menjadi semakin kompetitif maka, sangat penting bagi SDIT untuk secara terus-menerus meninjau faktor-faktor yang berdampak pada pilihan orang tua siswa dalam memilih SDIT. Untuk itu pengelola sekolah perlu melakukan riset pasar dan

${ }^{13}$ Fabio Vinicius De Macedo Bergamo, et.al., "Student Loyalty Based On Relationship Quality, " dalam Brazilian Business Review, Vol. 9 No. 2 Tahun 2012, hal. 26. 
menerapkan strategi pemasaran untuk mempengaruhi proses pengambilan keputusan orang tua.

Ditengah persaingan yang semakin kompetitif bersama SDIT lainnya, SDIT Lentera Ilmu harus berbenah untuk melakukan penelitian terhadap perilaku calon orang tua siswa untuk memilih dan masuk ke SDIT Lentera Ilmu. Untuk itu diperlukan bagi SDIT Lentera Ilmu dalam mengantisipasi implikasi pilihan jangka panjang serta memahami faktor-faktor kunci yang terlibat dalam pilihan orang tua siswa. Dengan memahami perilaku calon orang tua siswa akan memudahkan sekolah untuk menarik mereka ke sekolah tersebut. ${ }^{14}$

Banyaknya pilihan sekolah dasar membuat calon orang tua siswa menerima banyak pilihan dan informasi. Literatur untuk menjelaskan perilaku pada pemilihan sekolah secara sederhana dapat dibedakan dalam dua aliran pemikiran yang berbeda yakni rasional (functional) dan emosional (symbolic). Dalam konteks ini, faktor rasional merupakan hal penting. Namun pengaruh keterikatan emosional seperti orang tua, keluarga besar, juga merupakan faktor penting untuk diteliti.

Orang tua Muslim yang memilih anak-anak mereka untuk disekolahkan di sekolah keagamaan juga menggunakan kriteria dan ambang batas tertentu untuk membuat keputusan ini. Adapun landasan untuk ini adalah Aqeeda Islam (Creed). Dengan keyakinan mendalam bahwa ada Pencipta yang tidak hanya menciptakan kita tetapi juga menunjukkan kepada kita jalan yang benar untuk menjalani hidup kita, orang tua Muslim mencari cara terbaik, berdasarkan buktibukti yang diberikan dalam iman ini untuk membesarkan anak-anak mereka. Berdasarkan pengamatan dan penelitian pendahuluan di SDIT Lentera Ilmu, pilihan orang tua memasukkan anaknya ke SDIT Lentera Ilmu juga didasarkan pada alasan pilihan rasional dan emosional.

Secara emosional selain siswa, orang tua juga dibekali pelajaran membaca Al'Quran (Tahsin) tanpa dipungut biaya. Hal ini menyebabkan peningkatan kualitas membaca quran baik siswa maupun orangtua, sehingga orang tua bisa mendidik anak-anaknya di rumah untuk mengulang bacaan Al-Qur'an dengan metode yang benar. Namun disisi lain uang sekolah SDIT Lentera Ilmu masih terlalu mahal dibandingkan SDIT lainnya yang memiliki peringkat yang sama fasilitas yang masih terkesan biasa saja. Berdasarkan uraian latar belakang tersebut maka penulis tertarik untuk melakukan penelitian dengan judul "Pengaruh Persepsi Faktor Rasional dan Faktor Emosional Terhadap Kepuasan Orang Tua Siswa di SDIT Lentera Ilmu Kota Tangerang".

\section{B. METODE}

Metode Penelitian dalam pengertian yang luas dapat diartikan sebagai cara ilmiah, untuk mendapatkan data dengan tujuan dan kegunaan tertentu.

14 Gayla Rogers, et.al., "A Learner Needs Segmentations Leads To Improved Learner Satisfaction, " dalam Transformation In Higher Education, Vol. 11 Tahun 2006, hal. 401. 
Sugiyono $^{15}$ mengemukakan bahwa ada empat kata kunci yang perlu diperhatikan dalam menjelaskan metode penelitian, yaitu: cara ilmiah yang berarti kegiatan penelitian itu dilakukan berdasarkan pada karakteristik keilmuan, yakni rasional, empiris dan sistematis. Rasional yang berarti kegiatan penelitian itu dilakukan dengan cara-cara yang masuk akal, sehingga terjangkau oleh penalaran manusia. Empiris, yakni cara-cara yang dilakukan dalam penelitian dapat diamati oleh indera manusia, sehingga orang lain dapat mengamati dan mengetahui cara-cara yang digunakan. Sistematis, artinya proses yang digunakan dalam penelitian ini menggunakan langkah-langkah tertentu yang bersifat logis. Walaupun langkah-langkah penelitian antara metode kuantitatif, kualitatif dan Research and Developement (RED) berbeda, akan tetapi seluruhnya sistematis.

Berdasarkan uraian di atas, maka yang dimaksud metode penelitian adalah suatu proses ilmiah dalam rangka mendapatkan data dan informasi yang valid dengan tujuan untuk menemukan, mengembangkan dan membuktikan suatu hipotesis atau ilmu pengetahuan tertentu, sehingga dapat digunakan untuk memahami, memecahkan, dan mengantisipasi masalah dalam bidang tertentu.

Menilik uraian di atas, dan sesuai tingkat kealamiahan tempat penelitian, maka metode dalam penelitian ini mengunakan metode survei dengan pendekatan korelasional. Metode survai dipergunakan dengan pertimbanganpertimbangan bahwa penelitian dilakukan untuk mendapatkan data setiap variabel masalah penelitian dari tempat tertentu yang alamiah (bukan buatan) dengan alat pengumpul data berbentuk angket (kuesioner), test dan wawancara terstruktur dan berdasarkan pandangan dari sumber data, bukan dari peneliti.

\section{HASIL DAN PEMBAHASAN}

Kepuasan adalah sikap atau perilaku pelanggan secara keseluruhan terhadap perbedaan antara apa yang diharapkan pelanggan dan apa yang mereka terima, mengenai pemenuhan beberapa keinginan, kebutuhan atau tujuan. ${ }^{16}$ Kepuasan konsumen adalah hasil kolektif dari persepsi, evaluasi dan reaksi psikologis terhadap pengalaman konsumsi dengan produk atau layanan. Kepuasan konsumen di anggap sebagai cara konsumen mendapatkan lebih banyak manfaat dari pada biaya yang dikeluarkan mereka. ${ }^{17}$ Kepuasan pelanggan menurut Oliver adalah inti filosofi strategi pemasaran dari setiap

15 Sugiyono, Metode Penelitian Pendidikan Pendekatan Kuantitatif, Kualitatif, dan $R \mathcal{E} D$, Alfabeta, 2019, hal. 3 .

16 Philip Kotler dan Gary Amstrong, Principle Of Marketing, 16 edition, Pearson Education Limited, 2018.

17 Peter Verhoef, et.al., "The Effect Of Relational Constracts On Customer Referrals and Number Of Services Purchased From a Multi Service Provider, " dalam Journal Of The Academy Of Marketing Science, Vol. 30 No. 3 Tahun 2002, hal. 202-216. 
organisasi dan memainkan peran kunci dalam keberhasilan organisasi. ${ }^{18}$ Kepuasan pelanggan sangat penting untuk loyalitas merek. Kepuasan pelanggan secara tradisional di anggap sebagai penentu mendasar dari perilaku pelanggan jangka panjang. Kepuasan pelanggan didefinisikan sebagai evaluasi keseluruhan dari suatu produk perusahaan (atau jasa). ${ }^{19}$ Dalam literature pemasaran, kepuasan telah ditetapkan sebagai anteseden utama retensi pelanggan. Dalam konteks pemasaran hubungan, kepuasan dikonseptualisasikan sebagai elemen dari konsep kualitas hubungan. Pelanggan yang lebih puas, semakin besar retensi mereka, kata-kata positif yang dihasilkan melalui mereka dan keuntungan finansial bagi perusahaan yang melayani mereka. ${ }^{20}$

Kepuasan pelanggan memiliki korelasi kuat dengan kemauan melayani dengan baik. ${ }^{21}$ Sikap melayani, barangkali, tidak ada yang asing dengan istilah yang satu ini. Karena faktanya, kata ini sudah teramat sering kita dengar dan ungkapkan dalam kehidupan nyata keseharian. Bukan hanya itu saja, kaum laki-laki, perempuan, besar, kecil, tua, muda hingga (khususnya) kalangan pejabat dan birokrat acapkali menggunakan istilah yang sangat menawan tersebut. Disamping itu, tentunya sebagian orang sudah sangat memahami dan meyakini bahwa aktivitas manusia dimanapun mereka berdomisili tanpa memandang usia, gender, latar belakang pendidikan maupun status sosial lainnya secara umum berada diantara dua kutub ini, yaitu melayani dan dilayani.

Beberapa lembaga yang mengedepankan kepuasan pelanggan melalui kekuatan melayani, selalu menekankan pada seluruh karyawannya untuk memberikan pelayanan terbaik. Bahkan, pada lembaga tertentu membuat jargon "saatnya melayani". Tema yang sederhana namun bijak itu ternyata mengandung kekuatan aplikatif yang sangat luar biasa serta mampu menumbuhkan kesadaran dan membangkitkan energi hidup setiap personal siapapun dan pada posisi apapun didalam kehidupan sehari-harinya- untuk berbuat dan menghasilkan karya lebih baik dan banyak lagi pada masa mendatang.

Secara harfiyah kata melayani berasal dari kata dasar layan yang diapit oleh imbuhan me-i, sehingga membentuk kata kerja aktif. Sedangkan menurut Kamus Bahasa Indonesia, melayani bermakna membantu orang lain untuk

18 Richard L. Oliver, "Whence consumer loyalty?, " dalam Journal Of Marketing, Vol. 63 No. 1 tahun 1999, hal. 33-44.

19 Eugene W. Anderson, et.al., "Customer Satisfaction.Productivity and Provitability : differences between goods and services, " Marketing science, Vol. 16 No. 2 Tahun 1997, hal. 29-45.

20 Chatura Ranaweera, dan Jaideep Prabhu, “The Influence Of Satisfaction, Trust and Switching Barriers on Customer Retention in a Continuous purchasing Setting, " dalam International Journal of Service Industry Management, Vol. 14 No. 4 Tahun 2003, hal. 37-95.

${ }^{21}$ Agus W. Soehadi, A Value creation Approach: Strategi pemasaran dalam peningkatan nilai saham perusahaan, Jakarta: Prasetyaa Mulyaa Publishing, 2012, hal. 65. 
memenuhi kebutuhannya (sampai tuntas). Excellent Service, begitu orang sering memberikan istilah dalam sistem menejemen modern saat ini.

Dengan demikian, dapat dipahami bahwa di dalam kata melayani juga terkandung pengertian mendasar lainnya yang saling berkaitan. Diantaranya ialah adanya aktifitas fisik dan psikis dalam upaya saling berbagi, peduli, memberi, menyantuni, berempati, toleran, kasih sayang dan lain-lain yang dilakukan tanpa pamrih, tanpa mengkalkulasi untung-rugi, layaknya hitunghitungan dagang, untuk siapa, waktunya kapan, tempatnya dimana, caranya bagaimana, biayanya dari mana atau butuh tenaga berapa orang untuk mengerjakannya dan sederetan pertanyaan bernada was-was lainnya. Pembahasan tentang kepuasan, tidak terlepas dari pelayanan yang diberikan kepada pelanggan. Islam mengajarkan agar seseorang memberikan yang terbaik kepada orang lain. Hal ini tergambar dalam QS. Ali Imran/ 3: 134, sebagai berikut,

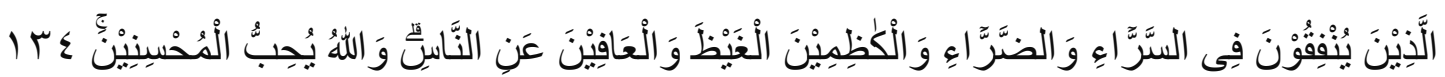

"(yaitu) Orang-orang yang menafkahkan hartanya, baik pada saat lapang maupun sempit, dan orang-orang yang menahan amarahnya dan memaafkan kesalahan orang. Allah menyukai orang-orang yang berbuat kebajikan." (QS. Ali-Imran: 134).

Al-Jalalain menafsirkan kalimat al-kâdzimîn al-ghaidz dengan kalimat alkâfina 'an imdlâihi ma'a al-qudrati (menahan hingga tidak melampiaskannya, walaupun sebenarnya dia sanggup untuk melampiaskan). Dalam kalimat al'âfina 'ani an-nâs ditafsirkan dengan miman dzolamahum ay al-târikîna 'uqûbatahum (meninggalkan pembalasan kepada orang yang melakukan keaniayaan kepadanya). ${ }^{22}$

Penafsiran Al-Jalalain tersebut memberikan pemahaman bahwa seseorang yang mengaku beriman hendaknya melakukan hubungan baik kepada orang lain. Dia dianjurkan untuk tidak menyakiti orang lain, bahkan dianjurkan untuk menahan amarah ketika orang lain melakukan kesalahan yang bersifat wajar.

Pemahaman di atas, jika diarahkan pada pelayanan, maka seseorang perlu memberikan pelayanan maksimal. Bisa jadi pelanggan memerlukan banyak hal supaya merasa puas atas permintaannya. Untuk memberikan kepuasan tersebut, seseorang perlu melakukan tindakan maksimal. Sebaliknya, jika pelanggan melakukan kesalahan, maka pemberi layanan dianjurkan untuk menahan amarahnya.

22 Jalaluddin Muhammad bin Ahmad bin Muhammad Al-Mahally dan Jalaluddin Abdurrahman bin Abi Bakr As-Suyuthy, Tafsir Al-Jalalain, Jakarta: Dar Al-Kutub Al-Islamiyah, 2011, hal. 115. 
Masalah kepuasan pelanggan telah mendapatkan perhatian yang meningkat di kalangan peneliti dan praktisi sebagai alat mendasar untuk meningkatkan kinerja organisasi dan profitabilitas. ${ }^{23}$ Untuk mengembangkan kepuasan pelanggan, keandalan dalam penyediaan layanan dan komitmen untuk hubungan layanan adalah suatu keharusan jika perusahaan harus berusaha untuk meningkatkan harapan pelanggan di masa depan.

Ada dua cara untuk mendefinisikan kepuasan pelanggan. Yang pertama adalah mempertimbangkan kepuasan sebagai hasil dari pengalaman konsumen dan respons emosional terhadap pengalaman yang tidak menilai harapan dengan cara apapun. Definisi kedua, mengambil kepuasan pelanggan sebagai proses untuk menilai harapan dan hasil yang efektif, itu adalah respon pelanggan untuk menilai perbedaan yang dirasakan antara harapan awal dan kinerja atau hasil efektif dari produk atau layanan.

Adaptasi konsep kepuasan dalam pendidikan diusulkan oleh Elliot dan Healy ${ }^{24}$ yang menunjukkan bahwa kepuasan orang tua siswa dihasilkan dari evaluasi pengalaman mereka dengan pendidikan yang diterima anak-anaknya. Kepuasan orang tua siswa didefinisikan sebagai "evaluasi subjektif siswa dari berbagai hasil dan pengalaman dengan pendidikan dan kehidupan sekolah". Kepuasan biasanya didasarkan pada evaluasi apakah harapan pelanggan telah dipenuhi serta besarnya konfirmasi atau diskonfirmasi harapan mereka. ${ }^{25}$

Guolla menunjukkan bahwa orang tua juga dapat mengambil peran sebagai klien, produsen, dan produk. ${ }^{26}$ Adalah siswa sebagai konsumen utama layanan pendidikan tinggi. ${ }^{27} \mathrm{O}^{\prime}$ Neill dan Palmer (2004) mendefinisikan kualitas layanan di sekolah sebagai perbedaan antara apa yang orang tua harapkan dan orang tua terima. Konsep penelitian kepuasan dalam sekolah dasar masih terbatas karena konsep kepuasan adalah konsep, yang kompleks dan terdiri dari beberapa dimensi. Dengan mengacu pada definisi kepuasan Oliver, deskripsi kepuasan orang tua adalah sebagai "evaluasi subjektif dari berbagai hasil dan

${ }^{23}$ Faizan Mohsan, et.al., "Impact of Customer Satisfaction on customer Loyalty and Intentions to switch, " dalam Pakistan:International Journal Of Business and Social Science, Vol. 2 no. 16 Tahun 2011, hal 1-11.

${ }^{24}$ Kevin M. Elliot dan Margareth A. Healy, "Key Factors Influencing Student Satisfaction Related To Recruitment And Retention. " dalam Journal of Marketing for Higher Education, Vol. 10 No. 4 Tahun 2001, hal. 1-11.

25 Helena Alves dan Mario Raposo, "Conceptual Model of Student Satisfaction in Higher Education, " dalam Total Quality Management \& Business Excellence, Vol. 18 No. 5 Tahun 2007, hal. 571588.

${ }^{26}$ Michael Guolla, "Assessing The Teaching Quality To Student Satisfaction Relationship: Applied Customer Satisfaction Research In The Classroom, " dalam Journal of Marketing Theory and Practice, Vol. 7 No. 3 Tahun 1999, hal. 87-97.

27 Dwayne D. Gremler, dan Michael A. McCollough, "Student Satisfaction Guarantees:An Empirical Examination Of Attitudes, Antecedentsn and Consequences, " dalam Journal of Marketing Education, Vol. 24 No. 2 Tahun 2002, hal. 150-260. 
pengalaman yang terkait dengan pendidikan, kepuasan di bentuk terus menerus oleh pengalaman berulang dalam kehidupan sekolah..$^{28}$

Berbagai dimensi kualitas kehidupan siswa di sekolah yang mencakup (administrasi dan layanan, suasana di antara siswa, daya Tarik kota sekitar nya, perangkat computer, kursus (kurikulum), perpustakaan, staff pengajar, ruangan kelas, kantin, relevansi mengajar dengan praktek, reputasi sekolah, penempatan sekolah, dukungan pengajar, informasi dan bangunan lingkungan fisik. ${ }^{29}$ Hasil penelitian mereka menunjukkan relevansi mengajar dengan praktek, dukungan dari pengajar, presentasi informasi, dan ruang kelas yang memiliki pengaruh positif dan signifikan terhadap kepuasan. Hasil penelitian lainnya juga mengungkapkan bahwa siswa yang puas dapat menarik siswa baru melalui positive word of mouth kepada keluarga, kenalan dan teman mereka agar masuk ke sekolah tersebut. Kepuasan siswa juga berdampak positif pada penggalangan dana dan motivasi siswa.

Jervis mendefinisikan rasional sebagai cara menafsirkan kenyataan yang sejalan dengan kaidah-kaidah dalam penarikan kesimpulan. ${ }^{30}$ Jadi berpikir rasional berarti seseorang menggunakan cara berpikir ilmiah. Dalam konteks ini segala asumsi, pemikiran, dan keyakinan seseorang harus dikesampingkan umtuk mencapai objektivitas, meskipun factor-faktor itu tetap berpengaruh. Dengan kata lain, ketika dihadapkan pada sebuah situasi sesorang mencoba mencari kecocokan antara apa yang diasumsikan dengan kenyataannya. Berpikir rasional juga bermakna seseorang cenderung menyederhanakan faktafakta ke dalam konsep umum yang sudah diterima. Dengan melakukan generalisasi seseorang lebih mudah memahami situasi yang sedang dihadapi sebelum mengambil keputusan.

Berpikir adalah suatu kegiatan mental yang melibatkan kerja otak. Akan tetapi fikiran manusia, walaupun tidak bisa dipisahkan dari aktifitas kerja otak lebih dari sekedar kerja organ tubuh yang disebut otak. dalam berfikir juga termuat kegiatan meragukan dan memastikan, merancang, menghitung, mengukur, mengevaluasi, membandingkan, menggolongkan, memilah-milah atau membedakan, menghubungkan, menafsirkan, melihat kemungkinankemungkinan yang ada. Membuat analisis dan sintesis menalar atau menarik kesimpulan dan premis-premis yang ada, menimbang dan memutuskan.

${ }^{28}$ Kevin M. Elliott dan Dooyoung Shin, "Student Satisfaction:An Alternative Approach To Assessing This Important Concept, " dalam Journal of Higher Education Policy and Management, Vol. 24 No. 2 Tahun 2002, hal. 197-209.

${ }^{29}$ Nara M. Martirosyan, et.al., "Student Satisfaction and Academic Performance In Armenian Higher Education, "dalam American International Journal of Contemporary Research, Vol. 4 No. 2 Tahun 2014, hal 1-5.

${ }^{30}$ Robert Jervis, "War and Misperception, " dalam Journal of Interdisciplinary History, Vol. 18 No. 4 Tahun 1988, hal. 675. 
Teori pilihan rasional menginformasikan sebagian besar rencana pilihan sekolah.Teori ini menunjukkan bahwa orang tua adalah pemaksimal utilitas yang membuat keputusan dari preferensi nilai yang jelas berdasarkan perhitungan biaya, manfaat, dan probabilitas keberhasilan berbagai opsi; bahwa mereka dapat menuntut tindakan efektif dari sekolah dan guru setempat; dan bahwa mereka dapat diandalkan untuk mengejar kepentingan terbaik anakanak mereka. ${ }^{31}$ Hatcher $\mathrm{R}$ menyatakan bahwa konteks pengambilan keputusan orang tua jauh lebih kompleks daripada hasil perhitungan rasional individu dari pengembalian ekonomi dari investasi mereka dalam pilihan pendidikan tertentu. ${ }^{32}$

Pilihan orang tua adalah bagian dari proses sosial dipengaruhi oleh sifatsifat yang menonjol dari kelas sosial dan jaringan hubungan sosial. ${ }^{33}$ Bahwa ketika seorang individu dihadapkan dengan keputusan penting, ${ }^{34}$ aktor rasional akan terlibat dalam pencarian informasi sebelum memutuskan. Namun, orang tua tampaknya menggunakan 'Campuran rasionalitas' yang melibatkan unsur 'kebetulan'. ${ }^{35}$ Untuk membuat keputusan mengenai pendidikan anak-anak mereka, orang tua akan bergantung pada nilai-nilai pribadi mereka dan tujuan pendidikan yang diinginkan, serta orang lain dalam jaringan sosial dan profesional mereka untuk mengumpulkan informasi. Orangtua, yang jaringannya tidak menyediakan akses ke informasi yang relevan dan berharga mengenai pilihan pilihan sekolah, terbatas dalam kapasitas mereka untuk membuat pilihan berdasarkan informasi. ${ }^{36}$

Pada hakikatnya, setiap orang mempunyai emosi. ${ }^{37}$ Dari bangun tidur pagi hari sampai waktu tidur malam hari. Kita mengalami macam-macam pengalaman yang menimbulkan berbagai emosi pula. Pada saat makan pagi bersama keluarga misalnya, kita gembira. Atau dalam perjalanan menuju kantor, menuju kampus, kita merasa jengkel karena jalanan macet sehingga setelah sampai di tempat tujuan, kita merasa malu karena dating terlambat, dan seterusnya. Semua itu merupakan emosi kita.

${ }^{31}$ J.K. Farrell, The Influence Of The Higher Education Service Cape On Campus Experience: University Of Hartford, 2014.

32 Richard Hatcher, "Class Differentation In Education Rational Choices?, " dalam British Journal Of Education, Vol. 19 No. 1 Tahun 1998, hal. 5-12.

${ }^{33}$ James S. Coleman, "Social Capital In The Creation Of Human Capital, " dalam American Journal of Sociology, Vol. 94 Tahun 1988, hal. 95-121.

${ }^{34}$ Diane Reay dan Stephen J. Ball, "Making Their Minds Up: Family Dynamics Of School Choice, " dalam British Educational Research Journal, Vol. 24 No. 4 Tahun 1998, hal. 431-449.

${ }^{35}$ Diane Reay dan Helen Lucey, "Children, School Choice And Social Differences, " dalam Educational Studies, Vol. 26 No. 1 Tahun 2000, hal. 83-101.

${ }^{36}$ Claire E. Smrekar dan Ellen Goldring, School Choice In Urban America: Magnet schools and the pursuit of Equity, New York: Teachers' College Press, 1999.

${ }^{37}$ Alex Sobur, Psikologi Umum,Bandung: CV.Pustaka Setia, 2016, hal. 345. 
Lalu, apakah sebenarnya yang dimaksud dengan emosi? Menurut William James dalam buku karangan Florence Wedge, menyatakan bahwa emosi adalah kecenderungan untuk memiliki perasaan yang khas apabila berhadapan dengan objek tertentu dalam lingkungannya. Crow dan Crow mengartikan emosi sebagai suatu keadaan yang bergejolak pada diri individu yang berfungsi sebagai inner adjustment (penyesuian dari dalam) terhadap lingkungan untuk mencapai kesejahteraan dan keselamatan individu. ${ }^{38}$ Dari definisi tersebut, jelas bahwa emosi tidak selalu jelek. Sebagaimana ungkapan Jalaluddin Rakhmat bahwa Emosi memberikan bumbu pada kehidupan, tanpa emosi, hidup ini kering dan gersang. ${ }^{39}$ Semua orang memiliki jenis perasaan yang serupa, namun intensitasnya berbeda-beda. Emosi-emosi ini dapat merupakan kecenderungan yang membuat kita frustasi, tetapi juga dapat menjadi modal untuk meraih kebahagiaan dan keberhasilan hidup. ${ }^{40}$

Berkaitan dengan itu, setidaknya ada empat fungsi emosi. ${ }^{41}$ Pertama, emosi adalah pembangkit energi (energizer). Tanpa emosi, kita tidak sadar atau mati. Hidup berarti merasai, mengalami, bereaksi dan bertindak. Emosi membangkitkan dan memobilisasi energi kita, marah menggerakkan kita untuk menyerang, takut menggerakkan kita untuk lari, dan cinta mendorong kita untuk mendekat dan bermesraan. Kedua, emosi adalah pembawa informasi (messenger). Bagaimana keadaan diri kita dapat diketahui dari emosi kita. Jika marah, kita mengetahui bahwa diri kita dihambat atau di serang orang lain, sedih berarti kita kehilangan sesuatu yang kita senangi, atau berhasil menghindari hal yang kita benci. Ketiga, emosi bukan hanya pembawa informasi dalam komunikasi interpersonal, melainkan juga pembawa pesan dalam komunikasi interpersonal. Berbagai penelitian membuktikan bahwa ungkapan emosi dapat dipahami secara universal. Keempat, emosi juga merupakan sumber informasi tentang keberhasilan kita. Kita mendambakan kesehatan dan mengetahuinya ketika kita merasa sehat wal afiat. Kita mencari keindahan dan mengetahui bahwa kita memperolehnya ketika kita merasakan kenikmatan estesis dalam diri kita.

Semua emosi pada dasarnya melibatkan berbagai perubahan tubuh yang tampak dan tersembunyi, baik yang dapat diketahui maupun tidak, seperti perubahan dalam pencernaan, denyut jantung, tekanan darah, jumlah hemoglobin, sekresi adrenalin, jumlah dan jenis hormon, malu, sesak nafas, gemetar, pucat, pingsan, menangis dan rasa mual. Emosi adalah pengalaman

38 Lester D. Crow, dan Alice Crow, Educational Psychology, New York: American Book Company, 1958, hal. 82.

39 Jalaluddin Rakhmat, Metode Penelitian Komunikasi, Bandung: Remaja Karya. 1984, hal. 56.

40 Alex Sobur, Psikologi Umum, ... hal. 346.

${ }^{41}$ James C. Coleman, dan Constance L. Hammen, Contemporary Psychology And Effective Behavior, Glenview: Scoot foresman and Co, 1974. 
yang dapat dirasakan secara fisik. ${ }^{42}$ Emosi merupakan system isyarat yang berfungsi sebagai alarm berupa informasi yang dibutuhkan dan mengarahkan ke berbagai jalan keluar, aksi atau perubahan pada saat tertentu. ${ }^{43}$ Menurut Goleman, emosi merujuk pada suatu perasaan dan pikiran khasnya, suatu keadaan biologis dan psikologis dan serangkaian kecenderungan untuk bertindak.44 Pengertian lain dari emosi merupakan luapan perasaan yang berkembang dan surut dalam waktu singkat dan reaksi psikologis dan fisiologis seperti: kegembiraan, kesedihan, kecintaan, keberanian yang subjektif. ${ }^{45}$

Para orang tua percaya menjadikan sekolah Islam sebagai tempat belajar untuk anak-anak mereka. Selain itu orang tua juga mengakui bahwa manfaat yang didapatkan bukan hanya untuk anak-anak mereka tetapi juga bermanfaat untuk diri mereka sendiri, yaitu bahwa memiliki anak-anak di sekolah Islam mendukung pengasuhan orangtua. Oleh karena sekolah Islam memperkuat apa yang diajarkan orangtua di rumah, upaya membesarkan anak bagi sebagian orang tua yang menyekolahkan anaknya di Sekolah Islam menjadi jauh lebih mudah. Orang tua mengakui bahwa jika anak-anak mereka bersekolah di sekolah non-Islam, akan ada konflik di antara nilai-nilai yang ditanamkan dirumah dan di sekolah, dan para orang tua harus bekerja lebih keras untuk menanamkan nilai-nilai Islam dalam hati dan pikiran anak-anak.

Keuntungan lain bagi orang tua adalah ketenangan pikiran yang mereka rasakan mengetahui bahwa anak-anak mereka aman, mengetahui dengan siapa anak-anak mereka bergaul, dan mengetahui bahwa anak-anak mereka dapat berlatih agama secara bebas dan nyaman tanpa menahan godaan atau perhatian negatif. Banyak orang tua merasa bahwa memiliki anak-anak mereka di sekolah Islam telah memberi mereka kesempatan untuk belajar dari dan dengan anakanak mereka. Ketika anak-anak mereka belajar tentang Islam, mereka sebagai orang tua belajar bersama dengan anak-anak. Beberapa orang tua merasa bahwa pengetahuan anak-anak mereka tentang Islam telah melampaui pengetahuan mereka sendiri, dan yang memperkuat apa yang diajarkan sekolah telah membantu mereka mempraktikkan agama mereka secara lebih baik.

Chapman dan Pyvis berpendapat bahwa model rasional tidak dapat menangkap citra multisensor, fantasi, kesenangan, dan emosi yang terkait

${ }^{42}$ Novianty Djafri, Manajemen Kecerdasan Emosi Untuk Kepala Sekolah, Gorontalo: Ideas Publishing, 2014, hal. 42.

${ }^{43}$ Jeanne A. Gardner, Bukan Seberapa Cerdas Diri Anda Tetapi Bagaimana Anda Cerdas, Terjemahan Arvin Saputra, Batam: Interaksara, 2004, hal. 18.

${ }^{44}$ Daniel Goleman, Kecerdasan Emosional, Terjemahan T. Hermany, Jakarta: Gramedia Pustaka Utama, 2001, hal. 411.

45 Robert K. Cooper dan Ayman Sawaf, Kecerdasan Emosional Dalam Kepemimpinan dan Organisasi, Terjemahan Alex Tri Kantjono Widodo, Jakarta: Gramedia Pustaka Utama, 2000, hal.15. 
dengan pengalaman konsumsi. ${ }^{46}$ Berbeda dengan pendekatan rasional, pendekatan emosional atau hedonis berpendapat bahwa motif konsumen bersifat emosional. Di bawah perspektif ini, individu menggunakan kriteria pribadi atau subjektif seperti rasa, kebanggaan, keinginan untuk mengekspresikan diri, dan mencapai tujuan emosional dalam keputusan konsumsi diri mereka. ${ }^{47}$

Zaltman menggarisbawahi bahwa setidaknya 95 persen dari semua kognisi terjadi di bawah kesadaran, dalam bayang-bayang pikiran sementara, paling banyak, hanya 5 persen terjadi dalam kesadaran tingkat tinggi. ${ }^{48}$ Perspektif rasional hanya mewakili puncak gunung es mental, sedangkan yang emosional melambangkan kedalaman yang tidak terduga. Sayangnya Penelitian empiris di bawah perspektif emosional kurang diteliti dalam sekolah. Atribut yang berfokus pada individu yang diteliti dalam aliran ini dapat dikelompokkan dalam nilai intrinsik seperti nilai-nilai pribadi(identitas), harapan dan pengaruh sosiokultural seperti keluarga, teman, dan hambatan dan dukungan kontekstual. ${ }^{49}$ Pemrosesan informasi dan emosi melibatkan sistem yang terpisah dan sebagian independen dan bahwa faktor-faktor kognitif dan afektif dapat berinteraksi satu sama lain. Kognisi dan emosi adalah pemikiran yang terpisah tetapi tetapi berinteraksi. ${ }^{50}$

\section{KESIMPULAN}

Kesimpulan dari penelitian yang telah dilakukan dapat dipaparkan sebagai berikut:

1. Terdapat pengaruh positif, kuat dan signifikan antara faktor rasional dengan kepuasan orang tua siswa, yang ditunjukkan oleh koefisien korelasi sederhana (ry.1) adalah 0,591 (korelasi kuat) dan koefisien determinasi $\left(\mathrm{R}^{2}\right)=$ 0,349 , yang berarti bahwa faktor rasional memberikan kontribusi terhadap kepuasan orang tua siswa sebesar $34,9 \%$ dan sisanya yaitu $66,1 \%$ ditentukan oleh faktor lain. Sedangkan persamaan regresi sederhana $\hat{Y}=25,058+0,591 X_{1}$, yang berarti bahwa setiap peningkatan satu unit skor faktor rasional akan

${ }^{46}$ Anne Chapman dan David Pyvis, "Quality, Identity And Practice In Offshore University Programmes: Issues in the internationalization of Australian higher education, "dalam Teaching in Higher Education, Vol. 11 No. 2 Tahun 2006, hal. 233-245.

47 Elizabeth C. Hirschman dan Morris B. Holbrook, "Hedonic Consumption: Emerging Concept, Methods And Propositions, " dalam Journal of Marketing, Vol. 46 No. 3 Tahun 1982, hal. 92101.

${ }^{48}$ G. Zaltman, How Customers Think: Essential Insight Into The Mind Of The Market: Boston, Harvard Business School Press, 2003.

49 Zeyneb Aycan dan Selda Fikret-Pasa, "Career Choices, Job Selection Criteria, And Leadership Preferences In A Transitional Nation: The case of Turkey, " dalam Journal of career development, Vol. 30 No. 2 Tahun 2003, hal. 129-144.

${ }^{50}$ Robert B. Zajonc, "On the primacy of affect, " dalam American Psycologist, Vol. 39 No. 2 Tahun 1984, hal. 117-123. 
memberikan kecenderungan terhadap peningkatan skor kepuasan orang tua siswa sebesar 0,591 .

2. Terdapat pengaruh positif, cukup kuat dan signifikan antara faktor emosional dengan kepuasan orang tua siswa, yang ditunjukkan oleh koefisien korelasi sederhana (ry.2) adalah 0,639 (korelasi cukup kuat) dan koefisien determinasi $\left(R^{2}\right)=0,408$, yang berarti bahwa kompetensi faktor emosional memberikan kontribusi terhadap kepuasan orang tua siswa sebesar 40,8\% dan sisanya yaitu $60,2 \%$ ditentukan oleh faktor lain. Sedangkan persamaan regresi sederhana $\hat{Y}=50,089+0,6538 X_{2}$, yang berarti bahwa setiap peningkatan satu unit skor kompetensi faktor emosional akan memberikan kecendrungan terhadap peningkatan skor kepuasan orang tua siswa sebesar 0,653.

3. Terdapat pengaruh positif, kuat dan signifikan antara faktor rasional dan kompetensi faktor emosional secara bersama-sama dengan kepuasan orang tua siswa, yang ditunjukkan oleh koefisien korelasi ganda (Ry.1.2) adalah 0,693 (korelasi kuat) dan koefisien determinasi $\left(R^{2}\right)=0,480$, yang berarti bahwa faktor rasional dan faktor emosional secara bersama-sama memberikan kontribusi terhadap kepuasan orang tua siswa sebesar 48,0\% dan sisanya yaitu 52,0\% ditentukan oleh faktor lain. Sedangkan persamaan regresi ganda $\hat{\mathrm{Y}}=12.269+0,444 \mathrm{X}_{1}+0,456 \mathrm{X}_{2}$, yang berarti bahwa setiap peningkatan satu unit skor faktor rasional dan faktor emosional secara bersama-sama akan memberikan kecendrungan terhadap peningkatan skor kepuasan orang tua siswa sebesar 0,900 . 


\section{DAFTAR PUSTAKA}

Abdullah, Mokhtar., Amjad D. Al Nasser, dan Nooreha Husain. "Evaluating Functional Relationship Between Image, Customer Satisfaction And Customer Loyalty Using General Maximum Entropy, " Total Quality Management, Vol.11 No. 4-6, 2010.

Abrasyi, Muhammad 'Athiyyah, al-Tarbiyah Al-Islamiyyah, Terjemahan. Abdullah Zakiy al-Kaaf. Prinsip-Prinsip Dasar Pendidikan Islam, Bandung: Pustaka Setia, 2003.

Abratt, Russel dan P.S.B Shee. "A New Approach To The Corporate Image Management Process, "Journal of Marketing Management, Vol. 4 No. 1, 1989.

Abu Zakaria Yahya Ibn Sharaf al-Nawawī, Syarhul 'Arba'in An Nawawi, Kairo: Daarul Mustaqbal, 2001, hal. 104.

Achmadi, Ideologi Pendidikan Islam, Yogyakarta: Pustaka Pelajar, 2005.

Al-Attas, Syed Muhammad Naquib. The Concept of education in Islam. London: Oxford, 1980.

Albin, Rochelle Semmel. Emotions, Philadelphia: The Westminster Press, 1983.

Ali, M., dan M Asrori. Psikologi Remaja, Perkembangan Peserta Didik. Jakarta: PT Bumi Aksara, 2006.

Alves, Helena dan Mario Raposo. "Conceptual Model of Student Satisfaction in Higher Education, "Total Quality Management \& Business Excellence, Vol. 18 No. 5, 2007.

Amanah, Dita. "Pengaruh Harga dan Promosi terhadap Kepuasan Konsumen Pada Majestyk Bakery dan Cake Shop Cabang H.M. Yamin Medan, "Jurnal Keuangan dan Bisnis, Vol. 2 No. 1, 2010.

Anderson, Eugene W. dan Marry W Sullivan. “The Antecedents And Consequences Of Customer Satisfaction For Firms, " Marketing Science, Vol. 12 No. 2, 1993.

Anderson, Eugene W., et al. "Customer Satisfaction, Productivity and

Profitability:Differences Between Goods and Services, "Marketing Science, Vol. 16 No. 2, 1997.

Bastaman, Hanna Djumhana, Integrasi Psikologi dengan Islam Menuju Psikologi Islam, Yogyakarta: Pustaka Pelajar, 1998.

Bergamo, Fabio Vinicius de Macedo., et al. "Student Loyalty Based On Relationship Quality, "Brazilian Business Review, Vol. 9 No. 2, 2012.

Berry, Leonard L., dan Manjit S.Yadav, “Capture and Communicate Value In Pricing 
of Services." Management Review Magazine, 1996.

Blattberg, Robert C., Gart Getz, dan Jacquelyn S. Thomas. Customer Equity Building and Managing Relationship as Valuuable Assets, Boston: Havard Business School Press, 2001.

Bock, Dora E., Sonja Martin Poole, dan Matthew Joseph. “Does Branding Impact Student Recruitment:Critical Evaluation, "Journal Of Marketing Of Higher Education, Vol. 24 No. 1, 2014.

Bolton, Ruth N. dan James H. Drew. "A Multistage Model Of Customer Assesment Of Service Quality and Value, "Journal Of Customer Research, Vol. 17 No. 4, 1991.

Briggs, Senga. "An Exploratory Study Of The Factors Influencing Undergraduate Student Choice: the case of higher education in Scotland, "Studies in Higher Education Journal, Vol. 31 No. 6, 2006.

Bukhari, Muhammad ibn Ismail. Shahih Bukhari, Mesir: Ad-Dar Al-Alamiyah, 2015, hal. 316.

Bungin, M. Burhan. Metodelogi Penelitian Kuantitatif : komunikasi, ekonomi, dan kebijakan publik serta ilmu-ilmu sosial lainnya. Jakarta: Kencana, 2005.

Carman, J.M. “Consumers Perceptions Of Service Quality: An Assesment Of The Servqual Dimension, "Journal Of Retailing, Vol. 66 No. 1, 1990.

Chaplin, C.P. Kamus Lengkap Psikologi, diterjemahan oleh Kartini Kartono, Jakarta: PT.Raja Grafindo Persada, 1993.

Chapman, Anne dan David Pyvs. "Quality Identity And Practice In OffShore University Programmes: issues in the internationalization of Australian higher education, "Teaching in Higher Education Journal, Vol. 11 No. 2, 2006.

Chi, Christina Geng-Qing dan Hailin Qu. "Examining The Structural Relationship Of Destination Image, Tourist Satisfaction and Destination Loyalty: An Integrated Approach, " Tourism Management, Vol. 29 No. 4, 2008.

Coleman, James Samuel. "Social Capital In The Creation Of Human Capital, " American Journal of Sociology, Vol. 94 No. 1, 1988.

Daft, Richard L. Era Baru Manajemen, diterjemahan oleh Tita Maria Kanita, Edisi ke 9, Buku 2. Jakarta: Salemba Empat, 2012.

Damartaji, Arisutha. Dimensi Kualitas Pelayanan, Jakarta: Gramedia Pustaka, 2005.

Darmansyah. Strategi Pembelajaran Menyenangkan Dengan Humor, Jakarta: Bumi Aksara, 2010.

Daryanto. Sari Kuliah Manajemen Pemasaran. Bandung: PT Sarana Tutorial Nurani Sejahtera, 2011.

Davies, Gary., et al. "A Corporate Character Scale To Asses Employee And Customer Views Of Organization Reputation, “ Corporate Reputation Review, Vol. 7 No. 2, 2004.

Departemen Agama Republik Indonesia. al-Qur'an dan Terjemahnya, Semarang: Toha Putra, 2002. 
Desmita. Psikologi Perkembangan. Bandung: PT Remaja Rosdakarya, 2008.

Djaslim Saladin. 2012. Manajemen Pemasaran, Analisis Perencanaan, Pelaksanaan, Unsur-unsur Pemasaran. Bandung: CV Linda Karya. 2012.

Dowling, Graham R. "Developing Your Company Image Into A Corporate Assets, " Long Range Planning, Vol. 26 No. 2, 1993.

Edwarson, Michael. "Measuring Customer Emotions In Service Encounters, An Exploratory Analisis, "Australasian Journal Of Market Research, Vol. 6 No. 2, 1998.

Efendi, A. Revolusi Kecerdasan Abad 21, Kritik MI, EI, SQ, AQ \& Successful Intelligence Atas IQ. Bandung: Alfabeta, 2005.

Eldorado H, Molden., Srikandi Kumandji, Edy Yulianto. "Pengaruh Kualitas pelayanan terhadap Kepuasan dan Loyalitas, "Jurnal Administrasi Bisnis, Vol 15 No 2, 2014.

Elliot, Kevin M dan Margareth A. Healy. "Key Factors Influencing Student Satisfaction Related To Recruitment And Retention, " Journal of Marketing for Higher Education, Vol. 10 No. 4, 2001.

Elliot, Kevin M. dan Dooyoung Shin. "Student Satisfaction:An Alternative Approach To Assessing This Important Concept, "Journal of Higher Education Policy and Management, Vol. 24 No. 2, 2002.

Engel, James F, dan Roger D. Blackwell. Perilaku Konsumen, Edisi Keenam, Jilid I. Jakarta : Binarupa. 1994.

Farrell, J.K. "The Influence Of The Higher Education Service Cape On Campus Experience, " University Of Hartford, 2014.

Fornel, Claes dan Birger Wenerfelt. “Defensive Marketing Strategy By Customer Complaint Management: A Theoretical Analysis, "Journal Of Marketing Research, Vol. 24 No. 4 , 1987.

Fraenkel, J dan N. Wallen. How to Design and Evaluate Research In Education.(2 ${ }^{\text {nd }}$ ed). New York:McGraw-Hill Inc.1993.

Gay, L.R dan P.L. Diehl, Research Methods For Business and Management, McMillan Publishing Company, New York, 1992.

Goleman, Daniel. Kecerdasan Emosi Untuk Mencapai Puncak Prestasi, Jakarta: Gramedia Pustaka Utama, 1999.

Gottman, John. Kiat-kiat Membesarkan Anak yang Memiliki Kecerdasan Emosional, Jakarta: Gramedia Pustaka Utama, 2003.

Gremler, Dwayne D. dan Michael A. McCollough. "Student Satisfaction Guarantees:An Empirical Examination Of Attitudes, Antecedents, and Consequences, " Journal of Marketing Education, Vol. 24 No. 2, 2002.

Gunawan, Imam. Metode Penelitian Kulitatif, Jakarta: Bumi Aksara, 2013.

Guolla, Michael. "Assessing The Teaching Quality To Student Satisfaction Relationship: Applied Customer Satisfaction Research In The Classroom, " Journal of Marketing Theory and Practice, Vol. 7 No. 3, 1999. 
Hadi, Sutrisno. Statistik, jilid 2. Yogyakarta : Andi. 2000.

Harris, Alma dan Steward Ranson. "The Contradictions Of education Policy: Disadvantage And Achievement, " British Educational Research Journal, Vol. 31 No. 5, 2005.

Haryono Sentot, Psikologi Shalat, Yogyakarta: Mitra Pustaka, 2001.

Hasan, Aliah B. Purwakania, Psikologi Perkembangan Islami (Menyingkap Rentang Kehidupan Manusia Dari Prakelahiran Hingga Pascakematian), Jakarta: Raja Grafindo Persada, 2006.

Hasyim, Muhammad, Dialog Antara Tasawuf dan Psikologi "Telaah Atas

Pemikiran Psikologi Humanistik Abraham Maslow", Yogyakarta: Pustaka Pelajar Offsett, 2002.

Hatcher Richard. "Class Differentation In Education Rational Choices?, " British Journal Of Education, Vol. 19 No.1, 1998.

Hawari, H. Dadang, IQ, EQ, CQ, dan $S Q$ "Kriteria Sumberdaya Manusia

(Pemimpin) Berkualitas", Jakarta: Balai Penerbit, 2003.

Hawkins, Delbert dan David Mothersbaugh. Consumer Behaviour.Building Marketing Strategy, Eleventh Edition, McGraw-Hill, 2010.

Heide, Morten, Gronhaug Kjell, dan Marit G Engset. "Industry Specific Measurement Of Consumer Satisfaction: Experience From The Business Travelling Industry, "International Journal Hospitality Management, Vol. 18 No. 2, 1999.

Hill, Francis M. “Managing Service Quality In Higher Education;The Role Of The Student as Primary Consumer, "Quality Assurances In Education, Vol. 3 No. 3, 1995.

Hirschman, Elizabeth C. dan Morris B. Holbrook. "Hedonic Consumption: Emerging Concept, Methods And Propositions, "Journal of Marketing, Vol. 46 No. 3, 1982.

Hude, M. Darwis. Emosi Penjelajahan Religio-Psikologis Tentang Emosi Manusia di Dalam Al-Qur'an, Jakarta: Erlangga, 2006.

Hurlock, E. B. Psikologi Perkembangan, Suatu Perkembangan Sepanjang rentang Kehidupan. Jakarta: Erlangga, 1980, Perkembangan Anak, jilid 1. Jakarta: Erlangga, 1997.

Indriantoro, Supomo. Metodologi Penelitian bisnis untuk Akuntansi dan Manajemen, Edisi Pertama. Yogyakarta : BPFE, 2002.

Irawan, Handi. 10 Prinsip Kepuasan Pelanggan. Jakarta : Elex Media Komputindo, 2003 Winning Strategy: Strategi Efektif Merebut dan Mempertahankan Pangsa Pasar, Jakarta: PT. Gramedia Pustaka Utama, 2002.

Irfan Fahmi. Manajemen Teori, Kasus dan Solusi. Bandung: Alfabeta, 2013.

Juanim. Analisis Jalur dalam Riset Pemasaran Teknik Pengolahan Data SPSS \& LISREL., Universitas Pasundan, Bandung, 2004.

Jumantoro, Totok. Psikologi Dakwah dengan Aspek-aspek Kejiwaan yang Qur'ani, Yogyakarta: Amzah, 2001. 
Kahfi, Ahmad. Emosional Learning Belajar Efektif Mengelola Emosi: Mengolah Kekuatan, Kemauan, dan Kecemburuan Menjadi Energi Kreatif "Osho", Yogyakarta: Pustaka Baca, 2008.

Kantspager, Roland dan Werner H. Kunz. "Consumer Trust In Service Companies: A Multiple mediating analysis, "Managing Service Quality: An International Journal , Vol. 20 No.1, 2010.

Kasmir. Etika Customer Service. Jakarta: PT. Raja Grafindo Persada, 2004.

Kau, Ah-Keng dan Elizabeth Wan-Yiun Loh. "The Effect Of Service Recovery on Consumer Satisfaction: A Comparison Between Complaints and Non Complaints, " Journal Of Service Marketing, Vol. 20 No. 2, 2006.

Kerlinger, Fred N. Asas-asas Penelitian Behavioral, edisi ketiga (terjemahan:Landung R.Simatupang), Yogyakarta, Universitas Gajah Mada Press, 1990.

Khaniwale, Manali, "Consumer Buying Behaviour, " International Journal of Innovation and Scientific Research, Vol. 14 No. 2, 2015.

Kotler, Philip dan A.B. Susanto. Manajemen Pemasaran Jasa Di Indonesia, Analisis Perencanaan, Implementasi Dan Pengendalian (Edisi Pertama). Jakarta : Salemba Empat, 2000.

Kotler, Philip dan Gary Amstrong. Principle Of Marketing:Prantice Hall, 2018.

Krippendorff, Klaus. Analisis Isi Pengantar Teori dalam Metodologi, Terjemahan. FaridWajidi, Jakarta: PT. Raja Grafindo Persada, 1993.

Lestari, Ayu Maya. “Analisis Persepsi Konsumen Mengenai Kualitas Pelayanan Dan Store Atmosphere, Serta Pengaruhnya Terhadap Loyalitas Konsumen (Studi Kasus : Restoran Tokyo Connection Bandung), "Jurnal Manajemen, Vol 4 No 1, 2017.

Lupiyoadi, Rambat. Manajemen Pemasaran Jasa. Jakarta : Salemba Empat, 2001.

Malhotra, N. K, J. Shaw Hall, M. Crisp. Marketing Research An Applied Orientation, Sydney: Prentice Hall, 2004.

Manz, Charles C., Emotional Disicipline, 5 Langkah Menata Emosi untuk Merasa Lebih Biak Setiap Hari, Jakarta: Gramedia Pustaka Utama, 2007.

Maringe, Felix. "Implication For Positioning. Recruitment and Marketing, " International Journal Of Educational Management, Vol. 20 No. 6, 2006.

Maria, Monica dan Mohamad Yusak Anshori. "Pengaruh Promosi terhadap kepuasan konsumen King Cake, "Jurnal Manajemen Teori dan Terapan, Vol. 6 No 1, 2013.

Martirosyan, Nara M., Patrick D. Saxon, dan Reubenson Wanjohi, "Student Satisfaction and Academic Performance In Armenian Higher Education, " American International Journal Of Contemporary Research, Vol. 4 No. 2, 2014.

McDoughall, Gordon H.G. dan Terrence Levesque. "Customer Satisfaction With Service:Putting Perceived Value Into The Equation, "Journal Of Service Marketing, Vol. 14 No. 5, 2000.

Miller, Katherine. Communication Theories: Perspectives, Processes, and contexts, New 
York: McGraw-Hill, 2005.

Mohsan, Faizan, et al. "Impact Of Customer Satisfaction On Customer Loyalty And Intentions To Switch:Evidence From Banking Sector Of Pakistan, “ International Journal Of Business And Social Science, Vol. 2 No. 16, 2011.

Muliawan, Ungguh Jasa. Epistemologi Pendidikan, Yogyakarta: Gadjah Mada University Press, 2008.

Nahlawi, Abdurrahman. Prinsip-Prinsip dan Metoda Pendidikan Islam dalam Keluarga, di Sekolah dan di Masyarakat, Bandung: CV.Diponegoro, 1996.

Narbuko, Cholid dan Abu Achmadi. Metodologi Penelitian, Jakarta: Bumi Aksara, 2007.

Nashori, Fuad. Agenda Psikologi Islami, Yogyakarta: Pustaka Pelajar, 2002.

------. Potensi-potensi Manusia "Seri Psikologi Islam", Pustaka Pelajar, 2003.

Newby, Tony dan Sean McManus. The Customer Service Pocketbook, Management Pocketbook Ltd, Hants, 2013.

Nguyen, Nha dan Gaston LeBlanc. "The Mediating Role Of Corporate Image On Cutomers Retention Decision: An Investigation In Financial services, " International Journal Of Marketing, Vol. 16 No. 2, 1998.

Novak, Joseph D. Meaningful Reception Learning As a Basic for Rational Thinking. New York: Cornell University, 1980.

Nuh, Sayyid Muhammad. Aafaatun 'Alath-Thariq, Mesir: Daarul Wafa, 1993.

Nurdan, dan Suhayati, "Berpakaian Islami Bagi Generasi Muda di Era Globalisasi Budaya Massa, “ Majalah Ilmiah BISSOTEK, Vol. 7 No. 1 Tahun 2012, hal. 5258.

O'Neill, Martin A dan Palmer, Adrian. "Importance-Performance Analysis: A Useful Tool For Directing Continous Quaity Improvement In Higher Education, “ Quality Assurance In Education, Vol. 12 No. 1, 2004.

Oliver, Richard L. “Whence Customer Loyalty?, “ Journal Of Marketing, Vol. 63 No. 1, 1999.

Oliver, Richard W. Satisfaction a Behavioral Perpective On The Customer. New York: McGraw, 1997.

Olorunniwo, Festus., Maxwell K. Hsu, Godwin J. Udo. “Service Quality, Customers Satisfaction, and Behavioral Intention In The Service Factory, " Journal Of Service Quality Marketing, Vol. 20 No. 1, 2006.

Pamenang, Wisnu. Pengaruh Kualitas Produk, Kepuasan Pelanggan dan Word Of Mouth Terhadap Minat Beli Ulang Konsumen Kerupuk Ikan Lele UKM Minasari Cikaria, Pati, Jawa Tengah, Universitas Diponegoro Lihat dalam : www.pasamanbaratkab.bps.go.id,2014. Diakses tanggal 17 Agustus 2019.

Pampaloni, Andrea M. "The Influence For Organizational Image On Collage Selection, "Journal of Marketing for Higher Education, Vol. 20 No. 1, 2010.

Parel, Cristina P. Sampling Design and Procedures. Philippines Social Science Council, 1994. 
Prasaranphanich. Perilaku Konsumen Analisa Model Keputusan. Yogyakarta: Universitas Atmajaya Yogyakarta, 2007.

Prasetyo, Bambang dan Lina Miftahul Jannah. Metode Penelitian Kuantitatif Teori dan Aplikasi. Jakarta: Raja Grafindo Persada, 2006.

Purwanto, Djoko. Komunikasi Bisnis. Jakarta: Erlangga, 2009.

Qomariah, N. Saat Anakku Remaja, Solusi Islam Menghadapi Permasalahan Remaja. Solo: PT Tiga Serangkai Pustaka Mandiri, 2011.

Rambat, Lupiyoadi. Manajemen Pemasaran Jasa. Jakarta: Salemba Empat. 2013.

Rambat, Lupiyoadi dan A. Hamdani. Manajemen Pemasaran Jasa Edisi 2. Jakarta: Salemba Empat. 2011.

Ranaweera, Chatura dan Jaideep Prabhu. “The Influences Of Satisfaction, Trust And Switching Barriers On Customer Retention In A Continuous Purchasing Setting, " International Journal Of Service Industry Management, Vol. 14 No. 4, 2003.

Rangkuti, Freddy. Konsep Pengukuran Kepuasan. Jakarta: PT. Gramedia Pustaka Utama, 2003.

Reay, Diane dan Helen Lucey. "Children, School Choice And Social Differences, “ Journal of Educational Studies, Vol. 26 No. 1, 2000.

Reay, Diane dan Steven J. Ball. "Making Their Minds Up: Family Dynamics Of School Choice, " British Educational Research Journal, Vol. 24 No. 4, 1998.

Rogers, Gayla., Donna S. Finley dan Margareth Patterson. “Transformation In Higher Education: A Learner Needs Segmentations Leads To Improved Learner Satisfaction, "Journal of Teaching in Higher Education, Vol. 11 No. 4, 2006.

Rosado, Delia Langa dan Miriam E. David. "A Massive University or University For Masses? Continuity and Change In Higher Education in Spain and England, " Journal of Education Policy, Vol. 21 No. 3, 2006.

Russeffendi, E.T. Dasar-dasar Penelitian Pendidikan dan Bidang Non Eksakta lainnya, Bandung : Tarsito, 1998.

Ruyter, Ko De., Jose Bloemer, Pascal Peeters. "Merging Service Quality and Service Satisfaction: An Empirical Test Of An Integrative Model. " Journal Of Economic Psychology, Vol. 18 No. 4, 1997.

Ryan, Aji Prasetyo. "Kualitas Pelayanan, Brand Image, dan Store Atmosphere sebagai diterminasi loyalitas konsumen dengan kepuasan konsumen sebagai Intervening, " Jurnal Ilmu Manajemen dan Riset, Vol. 4 No. 1, 2016.

Tafsir, Ahmad. Metodologi Pengajaran Agama Islam, Bandung: Remaja Rosdakarya, 2003.

Said, Usman dan Jalaludin. Filsafat Pendidikan Islam, Jakarta: Raja Grafindo Persada, 1999.

Saleh, Abdur Rahman. Pendidikan Agama dan Keagamaan, Visi, Misi dan Aksi,Jakarta: PT Gemawindu Pancaperkasa, 2000. 
Sangadji, E.M., dan Sopiah. Perilaku Konsumen: Pendekatan Praktis Penelitian Pemasaran. Bogor: Katalog Dalam Terbitan (KDT). 2013.

Schechter, L. A Normative Conception Of Value, Progressive Grocer, Executive Report, 1984.

Shaleh, A. R. Psikologi: Suatu Pengantar dalam Perspektif Islam. Jakarta: Kencana, 2009.

Shapiro, E. L. Mengajarkan Emosional Intelligence. Jakarta: Gramedia Pustaka Utama, 1997.

Shunhaji, Akhmad. Implementasi Pendidikan Agama di Sekolah Katolik Kota Blitar dan Dampaknya Terhadap Interaksi Sosial, Yogyakarta: Aynat Publishing, 2017, hal. 6.

Simamora, Bilson. Panduan Riset Perilaku Konsumen, Jakarta: Gramedia, 2004.

Smrekar, Claire dan Ellen Goldring. School Choice In Urban America: Magnet schools and the pursuit of Equity. New York: Teachers' College Press, 1999.

Soesilowindradini. Psikologi Perkembangan (Masa Remaja). Surabaya: Usaha Nasional, 1999.

Solomon, Miceal., et al. Consumer Behaviour. A European Perspective. Fourth Edition: Prentice Hall, 2010.

Suharsono. Melejitkan IQ, EQ, SQ. Jakarta: Ummah Publishing, 2009.

Sumarwan, Ujang. Perilaku Konsumen: Teori dan Penerapan dalam Pemasaran. Bogor: Ghalia Indonesia. 2011.

Sung, Minjung dan Sung-Un Yang. “Toward The Model Of University Image: The Influence of Brand Personality, External Prestige, and Reputation, " Journal of Public Relations Research, Vol. 20 No. 4, 2008.

Swastha, Basu. Azas-Azas Marketing, Yogyakarta: Liberty, 1999.

Syamsul, Yusuf. Psikologi Perkembangan Anak Dan Remaja, Bandung: Remaja Rosdakarya, 2000.

Taylor, Shelley E., Letitia Anne Peplau, dan David O. Sears. Psikologi Sosial, edisi kedua belas. Jakarta : Kencana. 2009.

Thohari, Hamim dan Ika Rais. Tumbuh Kembang Kecerdasan Emosi Nabi. Bekasi: Pustaka Inti. 2006.

Thomas, William. "Customer Satisfaction: Turning Temporary Scores Into Permanent Relationship, " Quality Progress, Vol. 31 No. 6, 1998.

Tjiptono, Fandy. Kepuasan dalam Pelayanan, Jakarta: Salemba Empat, 2004.

Trihendradi C. Step By Step SPSS 18 Analisis Data Statistik, Yogyakarta, Andi Offset, 2010.

------. Manajemen Jasa. Yogyakarta : Andi Offset, 1996.

------. Pemasaran Jasa. Malang: Banyu Media Publishing, 2007.

-----. Pemasaran Jasa. Malang : Bayumedia. 2004.

Umar, Husein. Studi Kelayakan Dalam Bidang Jasa, Cetakan Pertama. Jakarta : Gramedia, 2003.

Uqshari Yusuf, Ibhats'an Nuqaath An-Najaah. Gma Insani, Jakarta, 2006. 
-------. Kaifa Tafham Syakhsiyyaatak wa Tatakhal-lash min Salabiyyaatik?. Gema Insani Press, Jakarta, 2008.

Najati, Usman, Psikologi Dalam Al-Qur'an. Bandung: Pusaka Setia,2005.

------. Belajar EQ dan SQ dari Sunnah Nabi, diterjemahan oleh Irfan Salim, cetakan ke3, Jakarta: Hikmah, 2002.

Verhoef, Peter C., Philip Hans Frances dan Janny C. Hoekstra. "The Effect Of Relational Constructs On Does Age Of Relationship Matter?, " Journal Of The Academy Of Marketing Science, Vol. 30 No. 3, 2002.

Vincent, Carol., Annette Braun, dan Stephen Ball. "Local links, Local Knowledge: Choosing Care Settings And Schools, " British Educational Research Journal, Vol. 36 No. 2, 2010.

Walgito, B. Pengantar Psikologi Umum. Yogyakarta: ANDI. 2004.

Waskita, Alif Indar. "Pengaruh citra merek, harga dan promosi terhadap loyalitas konsumen, " Jurnal Ilmu dan Riset Manajemen, Vol. 5 No. 9, 2016. 